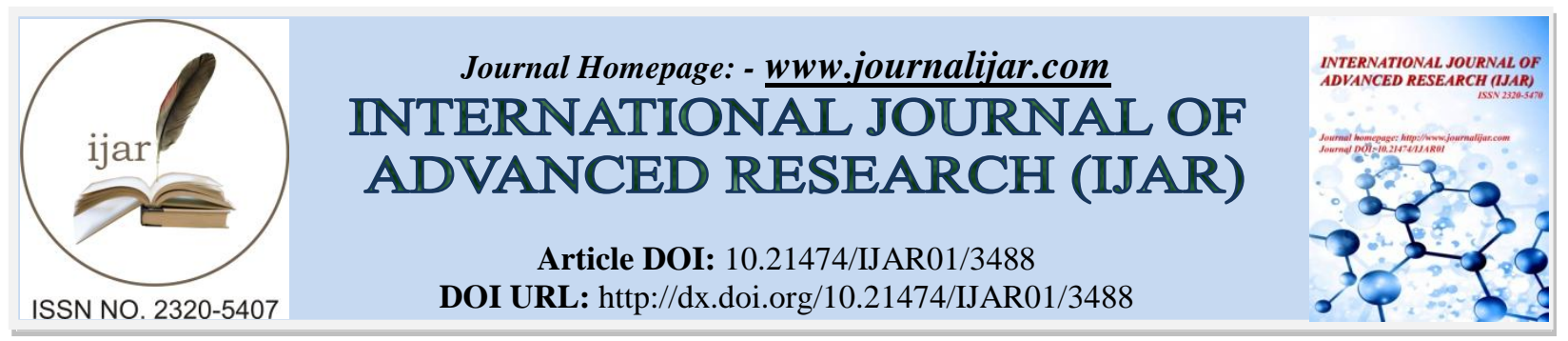

RESEARCH ARTICLE

\title{
INCIDENCE OF RH NEGATIVE BLOOD GROUP IN BLOOD DONORS FROM HIGH ALTITUDE AREAS OF JAMMU AND KASHMIR STATE, INDIA.
}

Naira Firdous Zargar ${ }^{1}$, ${ }^{*}$ Aleem Jan ${ }^{2}$, Arshad Hussan Siddiqie ${ }^{3}$, Javaid Rasool ${ }^{4}$ and Irfan Khan ${ }^{5}$.

1. Postgraduate Scholar, Dept Of Transfusion Medicine, SKIMS, Srinagar Jammu And Kashmir,India.

2. Additional Professor, Pediatric Hematology and Head Transfusion Medicine, SKIMS, Srinagar, Jammu and Kashmir, India.

3. Senior Resident, Dept Of Transfusion Medicine, SKIMS, Srinagar Jammu And Kashmir, India.

4. Professor and Head, clinical hematology, SKIMS, Srinagar, Jammu and Kashmir, India.

5. Senior Resident, Dept Of Transfusion Medicine, SKIMS, Srinagar Jammu And Kashmir, India.

\section{Manuscript Info}

Manuscript History

Received: 09 January 2017

Final Accepted: 10 February 2017

Published: March 2017

\begin{abstract}
According to presence or absence of antigens, human blood can be divided into different blood groups. Rh blood group is one of the most complex blood groups in humans. Rh positive has D antigen while Rh negative lacks the $\mathrm{D}$ antigen. This one year study was done in which 600 blood donors were tested for $\mathrm{Rh}$ blood group in the blood-bank laboratory by test-tube method. 300 blood donors were from high altitude areas (above 5500ft the sea level), while the 300 blood donors were from plain areas, of Jammu And Kashmir State, India. In high altitude blood group donors $87 \%$ were $\mathrm{Rh}$ positive while $13 \%$ were $\mathrm{Rh}$ negative. In plain area blood donors $93 \%$ were Rh positive while $7 \%$ were $\mathrm{Rh}$ negative. Thus there is a high incidence (13\%) of $\mathrm{Rh}$ negative donors in high altitude donors as compared to plain areas.
\end{abstract}

Copy Right, IJAR, 2017,. All rights reserved.

\section{Introduction:-}

Humans contain a series of glycoprotein's and glycolipids on the surface of RBC's which constitute the blood group antigens. According to presence or absence of antigens human blood can be classified into different blood groups like ABO blood group, MNS blood group, Rh blood group Etc. The international society of blood transfusion definition of the blood group system is where one or more antigens are controlled at a single gene locus or by two or more very closely liked homologous genes with little or no observable recombination between them (1).The Rh blood group is one of the most complex blood groups known in humans. It was named after Rhesus monkey. With 49 antigens so far described, it is largest of 29 blood group systems. Rh antigens are located on two Rhesus proteins RHD and RHCE. Rhesus proteins are expressed only in membranes of red blood cells (2).

ABO blood group system were discovered by Austrian pathologist Karl Landsteiner (3).

Following discovery of ABO, blood group, Rh antigen was discovered by Levine and Stetson in 1939 (4).

Among the Rh antigens D,C,c,E and e are most important which are encoded by two adjacent gene loci, the RHD gene which encodes the RHD protein with the D antigen and variants(5).

Corresponding Author:- Aleem Jan.

Address:- Additional Professor, Pediatric Hematology and Head Transfusion Medicine, SKIMS, 
The RhCE gene which encodes RhCE protein with the C,E,c and e antigens and variants. Gene for Rh system is located on chromosome 1 (6).

$\mathrm{Rh}$ positive and $\mathrm{Rh}$ negative refer to $\mathrm{D}$ antigens only. $\mathrm{Rh}$ positive has $\mathrm{D}$ antigen and $\mathrm{Rh}$ negative does not have $\mathrm{D}$ antigen.

Incidence of $\mathrm{Rh}$ blood groups varies in different parts of world. Factors attributed to such difference include racial differences, geographical variation, external environment and genetic makeup $(7,8,9)$.

The Caucasians of European descent have highest incidence of Rh negative phenotype (15-17\%). It is less common in Africans, in Asians it is less than 1\% (10).

$\mathrm{Rh}$ antigens, especially D are highly immunogenic. They have been implicated in hemolytic disease of newborn and hemolytic transfusion reactions. The knowledge of distribution of Rhesus blood group at local and regional levels is helpful in the effective management of blood banks and safe blood transfusion service (11).

\section{Materials and methods:-}

This prospective one year study was conducted from Nov 2015 to Nov 2016 in the department of blood bank of Sher-i-Kashmir Institute of Medical Sciences, Srinagar, India which is a deemed university, super specialty hospital of north India. This study was done to find out incidence of Rh negative blood group among donors belonging to high altitude areas (5500ft above the sea-level) of Jammu and Kashmir (sample size 300). This was compared with incidence of Rh negative blood group among donors belonging to plain areas (sample size 300). Both voluntary and replacement donors were included in the study. Donors were selected strictly as per AABB's (American association of blood bank) recommendation.

\section{Procedure:-}

Three methods are available for detecting $\mathrm{Rh}$ antigens, e.g. slide method, tube method and micro-plate or micro-well method. We selected test-tube method for our study, as it is simple, reliable, cost effective method. It allows for long incubation without any drying, unlike slide method which causes drying, of blood giving at times false impression of agglutination. The tubes can further be centrifuged to enhance antigen-antibody reaction.

\section{Requirement \& Material:-}

- $75 \mathrm{x} 10 \mathrm{~mm}$ tubes

- Test serum Igm monoclonal Anti D/ saline Anti D

- $\quad$ Test red cells

- $\quad \mathrm{Rh}$ positive and Rh negative control cells ( for monoclonal Anti D)

\section{Methods:-}

A detailed history and physical examination of donors was done. Their residential address, age and sex was noted. After taking informed consent of donors, blood samples were collected under all aseptic precautions. 300 blood samples were collected from high altitude areas donors (5500ft above the sea level). 300 blood samples were collected from non hilly areas or plain areas .

$2-4 \%$ washed red cell suspension of test sample was prepared. To one drop of 2-4\% red cell suspension 2 drops of anti $\mathrm{D}$ serum was added and was mixed by gently shaking the tube. The test tube was incubated at room temp for 60 minutes. Agglutination was seen against a well-lit background. Results, were recorded. All negative results were checked using a microscope. Relevant data was collected using a proper proforma form.

\section{Result:-}

1. A total of 600 donors, 300 each from high altitude areas ( above 5500ft) and plain areas were screened for Rh typing.

2. Out of 300 donors of high altitude areas $291(97 \%)$ were males while as $9(3 \%)$ were females. In plain areas donors $288(96 \%)$ were males and $12(4 \%)$ were females.

3. In high altitude group donor, the age group of $18-30$ years comprised $65 \%$ of the total donor.In plain area donors, this age group comprised $51 \%$ of total donors. 
4. In high altitude group donors 261 donors $(87 \%)$ were $\mathbf{R h}$ positive while as $39(13 \%)$ were Rh negative.In plain area group donors, $279(93 \%)$ were $\mathrm{Rh}$ positive while as $21(7 \%)$ donors were $\mathrm{Rh}$ negative. Thus there is a high incidence of $\mathrm{Rh}$ negative group in high altitude area donors $(13 \%)$, which is the salient feature of this study.

5. In high altitude area donors, of 291 males, 252(86.6\%) were $\mathrm{Rh}$ positive and 39(13.4\%) were $\mathrm{Rh}$ negative. Among females all 9 (100\%) were Rh positive with no Rh negative females, were found.

6. In plain area donors out of 288 males, 267(92.7\%) were Rh positive and 21(7.3\%) were Rh negative. Among females all21(100\%) were $\mathrm{Rh}$ positive with no $\mathrm{Rh}$ negative females, were found.

7. In high altitude area donors the most common blood group was found to be $\mathrm{B}+\mathrm{ve}(35 \%)$, while as in plain area donors two blood group were commonest. It was found to be $\mathrm{B}+\mathrm{ve}(33 \%)$ and $\mathrm{O}+\mathrm{ve}$ also (33\%).

8. In high altitude area donors, the least common blood group was found to be AB-ve (1\%), while in plain area donor group no AB-ve donor was found $(0 \%)$.

\section{Discussion:-}

Blood groups are genetically determined. The incidence of $\mathrm{ABO}$ and $\mathrm{Rh}$ genes and their phenotypes vary widely across races and geographical boundaries. The resultant polymorphism remains important in population genetic studies, estimating the availability of compatible blood, evaluating the probability of hemolytic disease in new born, resolving disputes of paternity/ maternity and for forensic purposes.

In the present study among high altitude donors $87 \%$ were $\mathrm{Rh}$ positive and $13 \%$ were $\mathrm{RhD}$ negative. Among donors of plain areas $93 \%$ were $\mathrm{RhD}$ positive and $7 \%$ were $\mathrm{RhD}$ negative .Incidence of $\mathrm{RhD}$ antigen in most parts of india varies from $91-98 \%$ for $\mathrm{RhD}$ positive and 2-9\% for Rh D negative. In Britain and U.S.A , the distribution of RhD positive is $83 \%$ and $85 \%$ respectively with $\mathrm{RhD}$ negative of $17 \%$ and $15 \%$ respectively (12).

It is postulated that ancestors of high altitude area donors, of Jammu and Kashmir state, India have migrated from central and south east Asia the erstwhile silk route which have a similar pattern of distribution.

In six muslim dominated districts of Aligarh, Uttarpradesh, what surfaced as a contrast was $15 \%$ incidence of Rh negative blood groups. It supports the ancestry background from middle east.

The comparison of frequency and distribution of Rh blood groups in blood donors of high altitude population and plain regions of Jammu and Kashmir, India with the studies carried out at national and international level is given in table 1 and table 2.

Table no 1:- Comparison of present study with Indian studies (in percentage).

\begin{tabular}{|l|l|l|}
\hline RH D & Rh positive & Rh negative \\
\hline Present study & & $13 \%$ \\
$\bullet \quad$ High altitude areas & $87 \%$ & $7 \%$ \\
\hline Plain areas & $93 \%$ & $5.79 \%$ \\
\hline Chittoor (14) & $94.2 \%$ & $8.42 \%$ \\
\hline Vellore (15) & $90.6 \%$ & $5.47 \%$ \\
\hline Shimoga- Malnad(16) & $94.5 \%$ & $5 \%$ \\
\hline Davangere(17) & $94.9 \%$ & $5.5 \%$ \\
\hline Eastern ahmedabad (18) & $94.8 \%$ & $5.8 \%$ \\
\hline Punjab (19) & $94.2 \%$ & $2.7 \%$ \\
\hline
\end{tabular}

Table no 2:- Comparison with studies outside India (in percentage).

\begin{tabular}{|l|l|l|}
\hline Study & Rh D Positive & Rh D Negative \\
\hline Present study & & \\
$\bullet \quad$ High altitude & $87 \%$ & $13 \%$ \\
$\bullet \quad$ Plain area & $93 \%$ & $7 \%$ \\
\hline Pakistan (20) & $89.1 \%$ & $10.9 \%$ \\
\hline Nepal (21) & $96.7 \%$ & $3.3 \%$ \\
\hline Britain (22) & $83 \%$ & $17 \%$ \\
\hline
\end{tabular}




\begin{tabular}{|l|l|l|}
\hline USA (23) & $85 \%$ & $15 \%$ \\
\hline Niger Delta(24) & $93.9 \%$ & $6.1 \%$ \\
\hline
\end{tabular}

The knowledge of distribution of Rh D negative blood groups is essential for the effective management of blood bank's inventory. The study data would help in establishment of more efficient blood transfusion service that would meet the increasing demand for Rh D negative blood groups. Voluntary blood donation camps can be organized in high altitude areas, so that resources for Rh negative bloodgroups, can be tapped. For this the general public of the area need to be motivated.

\section{Conclusion:-}

The study showed high incidence of Rh D negative blood group (13\%) in population of high altitude areas (5500ft above sea level), of Jammu and Kashmir state, India. This incidence was almost double (7\%) as compared to the plain areas in studied area. It is hoped that the study data generated will help in establishment of more efficient functioning blood transfusion service especially the need for negative blood groups. It could also help formulate robust marrow registries in India a process in infancy yet.

\section{References:-}

1. ISBT committee on terminology for red cell surface antigens. (available from www.isbtweb.org)

2. Flegel WA, Wagner FF. Blutgrupen : AlloantigensautErythrozen. In :Mueller -Eckhardtc, kiefel V, editors. Transfusionsmedizin. Bulin: Berlin Springer :2003: 145-148.

3. Landsteiner $\mathrm{k} \quad$.UeberagglutinationserscheinungennormalenmenschilichenBlutes $\quad$.Wien $\quad$ Klin. Wochenschr.1901,14:1132-1134

4. Levin Philip, Rufus E Stetson- An unusual case of Intragroup agglutination J Am Med Asso.133(2):126127,1939

5. RHD Rh group, D antigen (homo sapiens )-Gene result n/m.nih.gov. retrieved 2010,06-15.

6. RHCE Rh blood group, CcEe antigens (Homosapiens)-Gene Result nlm.nih.gov.retrived 2010;06-15.

7. Hospital, kingnet.com.Fw.retrived 2010,8-10

8. DacieJV,lewis SM. Practical hematology in: lewis SM ,Bain BJ, Bates I, Editors, $9^{\text {th }}$ edition London :Churchill livingstone, Harcourt publisher ltd ; 2001, pg444-51.

9. Reid ME, lomas- francis C. The blood group antigens facts book. Sane Diego: Academics press; 1997.

10. Mollison PL, Engelfriet CP, ConterasM.The Rh blood group system. In blood transfusion in clinical medicine, $9^{\text {th }}$ edition, Oxford: Black well scientific publication. 1993, 2008-9.

11. Patel P, Sangeeta P, Jigesh S, Haren O, Frequency and distribution of blood groups in donors in western Ahmedabad -A hospital based study. National J Med Res 2012; 2(2):202-6.

12. KhanchaAhuja,Ranjan Kumar satapathy, Vanshreesingh, Surindersingh( 2015). Prevalence and distribution of $\mathrm{ABO}$ and Rh-D antigens in Delhi-National capital region ; International journal of technical research and applications :2320-8163, Volume 3, Issue 6 ( nov-dec,2015) Pg ,1-6

13. Periyavan A,Sangeetha SK, Marimuthu P, Manjunath BK, Seema. Distribution of ABOand Rh-D groups in and around Bangalore. Asian J transfusSci 2010;4:41

14. Reddy KSN ,Sudha G and Rh(D) blood groups among the desuriReddis of Chittoor District, Andra Pradesh Anthropologist. 2009;11 (3):237-238

15. Das PK, Nair Sc, Haris VK, Rose D, Mammen JJ, Bose YN, Sudarsanam A Distribution of ABO and Rh-D blood groups among blood donors in a tertiary carecentre in south India. Trop Docit 2001;31:47-8

16. Girish CJ, Chandrashekhar TN, Ramesh Babu K, Kantikar SM, ABO and Rhesus blood group distribution among Malnad region blood Donors research and reviews in Biomedicine and biotechnology [RRBB]. 2011;2(3):25-30

17. Mallikarjuna S Prevalence of $\mathrm{ABO}$ and Rhesus blood group among blood donors.Ind J Pub Health Research and development 2012;3:106-9

18. Wadhwa MK, Patel SM, Kothari DC, Pandey M, Patel DD. Distribution of ABO and Rhesus D groups in Gujrat, India-a Hospital Based Study. Indian J PedOncol 1998; 19: 137-41

19. Sidhu S, Distribution of ABO blood groups and $\mathrm{Rh}(\mathrm{D})$ factor among the scheduled caste population of Punjab. Anthropologist 2003;5:203-4

20. Hammed A, Hussain W, Ahmed J, Rabbi F, Qureshi JA. Prevalence of Phenotypes and Genes of ABO and Rhesus (Rh) blood groups in Faisalabad, Pakistan. PakbiolSci 2002;5:722-724 
21. Pramanik T,Pramanik S. Distribution of $\mathrm{ABO}$ and $\mathrm{Rh}$ blood groups in Nepalese medical Student: a report. Eastern Mediterranean Health J 2000;6(1):156-158

22. Frances TF: Blood groups (ABO groups).In : Common Laboratory and Diagnostic Tests. $3^{\text {rd }}$ Edition, Philadelphia: Lippincott, 2002;P:19-5

23. Mollison PL, EngelFriet CP, Conteras M. The Rh blood group system. In blood transfusion in clinical Medicine, $9^{\text {th }}$ Edition. Oxford : Black well Scientific Publication. 1993;2008-9

24. Enosolease ME, Bazuaye GN: Distribution ofABO and Rh-D blood groups in the Benin area of Niger-Delta: Implication For regional blood transfusion. Asian J TransfSci 2008;2(1): 3-5 